\title{
TRIPS, TRADEMARKS, AND TRADEMARK \\ TRANSACTIONS: A FORCED RECONCILIATION?
}

\author{
Daniel J. Gervais*
}

\begin{tabular}{|c|c|c|c|c|c|}
\hline A. & INTRODUCTION & 1.01 & & $\begin{array}{l}\text { 3. Recordal of transfers and licenses } \\
\text { under Article } 19.2 \text { of the TRIPS }\end{array}$ & \\
\hline B. & THE ORIGIN OF THE TRADEMARK & & & Agreement & 1.29 \\
\hline & PROVISIONS IN THE TRIPS AGREEMENT & 1.03 & & 4. Article 20 of the TRIPS Agreement & 1.36 \\
\hline & $\begin{array}{l}\text { 1. The battle between common and } \\
\text { civil law }\end{array}$ & 1.03 & D. & THE TRADEMARK TRANSACTIONS & \\
\hline & 2. Trademarks in major legal systems & & & PROVISION: ARTICLE 21 OF THE TRIPS & \\
\hline & and the TRIPS Agreement & 1.08 & & AGREEMENT & 1.43 \\
\hline & 3. The TRIPS Agreement and the Paris & & & 1. Drafting history & 1.44 \\
\hline & Convention & 1.14 & & $\begin{array}{l}\text { 2. Compulsory licenses of trademarks } \\
\text { 3. Conditions on transfers and licenses }\end{array}$ & 1.49 \\
\hline C. & THE TRADEMARK PROVISIONS IN THE & & & and the enforcement of marks & 1.54 \\
\hline & TRIPS AGREEMENT & 1.17 & & 4. A role for competition law? & 1.62 \\
\hline & 1. Article 15 of the TRIPS Agreement & 1.18 & & & \\
\hline & 2. The function(s) of trademarks & 1.20 & E. & CONCLUSION & 1.70 \\
\hline
\end{tabular}

\section{A. INTRODUCTION}

The World Trade Organization's (WTO) Agreement on Trade-Related Aspects of Intellectual Property Rights (TRIPS Agreement) ${ }^{1}$ imposes limits to, and certain parameters for, the regulation by WTO Members of trademark transactions, such as licenses and assignments. WTO Members can challenge each other's measures implementing these provisions if they believe another Member's trademark rules violates the TRIPS Agreement using the WTO dispute-settlement system. ${ }^{2}$

* Professor of Law, Vanderbilt Law School.

1 Agreement on Trade-Related Aspects of Intellectual Property Rights, 15 April 1994, Marrakesh Agreement Establishing the World Trade Organization, Annex 1C, 1869 U.N.T.S. 299, 33 I.L.M. 1197 (1994) [hereinafter TRIPS Agreement].

2 TRIPS Agreement, supra note 1, Art. 64; Understanding on Rules and Procedures Governing the Settlement of Disputes, 15 April 1994, Marrakesh Agreement Establishing the World Trade Organization, Annex 21869 U.N.T.S. 401, 33 I.L.M. 1226 (1994) [hereinafter DSU]. 
1.02 This Chapter examines, first, the source of trademark provisions in the TRIPS Agreement and specifically whether they accord with common law or civil law trademark law and practice. It then considers the TRIPS Agreement provisions that are most likely to impact trademark transactions. After a review of Articles 15, 19 and 20 of the TRIPS Agreement, which at least indirectly impact trademark transactions, the Chapter devotes a separate part to Article 21 , which provides rules applicable to licenses, transfers and assignments of trademarks.

\section{B. THE ORIGIN OF THE TRADEMARK PROVISIONS IN THE TRIPS AGREEMENT}

\section{The battle between common and civil law}

1.03 Like most other sections of the TRIPS Agreement, the trademark section is a compromise. While that compromise was not always between the same two positions, the differences between the two major legal systems, namely common law and civil law, do emerge rather frequently in the text. Indeed, one could attribute a score to determine which 'side' won the debate on each section of Part II of the TRIPS Agreement (that is, the part that contains the norms concerning substantive IP rights, including trademarks).

1.04 For example, common law 'scored' a major win in copyright. The TRIPS Agreement's incorporation, by reference, of the substantive provisions of the Berne Convention for the Protection of Literary and Artistic Works (Berne Convention), whose origins are deeply rooted in the soil of continental Europe, may not seem like a win. ${ }^{3}$ However, by the time the TRIPS Agreement was signed in Marrakesh on 15 April 1994, the Berne Convention had become an unavoidable point of reference, with 107 Member States at the time, ${ }^{4}$ especially with the addition of the United States in 1989. Short of rewriting the Berne Convention ex nibilo, which would have implied huge transition costs, the acceptance of the Berne Convention was unavoidable. ${ }^{6}$ Of course, the victory of common law was not in accepting the reference to the

3 Sam Ricketson \& Jane C. Ginsburg, The Berne Convention - Historical and Institutional Aspects, in INTERnational Intellectual Property: A Handbook of Contemporary Research 3 (Daniel J. Gervais ed., 2015).

4 Berne Convention Member List, available 14 September 2015 at http://www.wipo.int/export/sites/www/ treaties/en/documents/pdf/berne.pdf. As of December 2014, the Convention has 167 Member States.

5 The United States became a party to the Berne Convention with effect from 1 March 1989. See id. at 13.

6 Daniel Gervais, The TRIPS Agreement: Drafting History and Analysis 143-147 (4th ed. 2012) [hereinafter GERVAIS, TRIPS AGREEMENT]. 
Berne Convention. The success was in getting the countries Members of the WTO to agree to the following: (a) to remove the notion of 'author' and replace it with the more economic and utilitarian notion of 'right holder': and (b) to eviscerate the moral right by making it impossible to enforce at the WTO.

The patent section of the TRIPS Agreement is a more complex analysis owing in large part to the fact there was no unified front of common law jurisdictions. In fact, the majority of such jurisdictions though definitions in domestic law varied considerably identified patentability criteria using terminology similar to that used in civil law countries. Hence, the patentability criteria found in Article 27.1 of the TRIPS Agreement are named (but not defined) as 'inventive step' and 'industrial applicability' and not as the North American concepts of non-obviousness and utility, which are merely identified in a footnote as possible deemed synonyms. ${ }^{7}$ The patent section of the TRIPS Agreement is thus perhaps best seen as a draw. ${ }^{8}$

As we get closer to trademarks, one could mark the section on geographical indications (Articles 22 to 24) as a victory for civil law. That would be incorrect, or at least an oversimplification. The number of countries interested in a higher level of protection of geographical indications has increased over the past few years, as the renewed interest in the Lisbon Agreement on the Protection of Appellations of Origins (Lisbon Agreement) at the World Intellectual Property Organization (WIPO) has shown. ${ }^{9}$ The debate has not been between common law and civil law as much as it has been between the 'Old World' and 'New World'. ${ }^{10}$ Now a path forward is emerging as 'New World' nations recognize the value of geographical identifiers, from Napa (U.S.) or Marlborough (New Zealand) wines to Colombian coffee to Mexican crafts and tequila. ${ }^{11}$ In fact, a Diplomatic Conference which should adopt a revised version of the Lisbon Agreement is scheduled to be held in 2015.12

7 In other words Canada and the United States did not have to modify their national law because the notions of utility and non-obviousness 'may be deemed to be synonymous' with industrial application and inventive step, respectively.

8 It is no surprise that the terms used by a vast majority of countries are in the main article and the Canada/US version relegated to the footnote.

9 World Intellectual Property Organization [WIPO], Draft Revised Lisbon Agreement on Appellations of Origin and Geographical Indications, LI/WG/DEV/8/2 (2011), available 14 September 2014 at http://www.wipo.int/ meetings/en/doc_details.jsp?doc_id=252459.

10 See Daniel Gervais, Reinventing Lisbon: The Case for a Protocol to the Lisbon Agreement, 11 CHI. J. INT'L L. 67, 67-126 (2010) (discussing the delineation of the border between geographical indications and existing trademarks in Articles 22.3, 23.2 and 24.5).

11 See id.

12 Preparation of the Final Stages of the Negotiation of a Revised Lisbon Agreement, WIPO (14 July 2014), available 14 September 2014 at http://www.wipo.int/lisbon/en/news/2014/news_0004.html. 
1.07 Independently of which side 'scored' higher in the negotiation of any section of the TRIPS Agreement, the exact measure of the victory sometimes remains unclear. WTO Members run the risk of having the TRIPS Agreement interpreted in ways that were not entirely foreseen during the negotiation. For example, the panel that examined the European Union's (EU) regime for the protection of geographical indications seemed to confirm that maintaining a 'first in time, first in right' approach to the interface between trademark rights and geographical indications was acceptable in most cases. ${ }^{13}$ The disputesettlement panel found that the EU regime that accords higher protection to geographical indications where there was a conflict with a (non famous) pre-existing trademark was an acceptable exception to trademark rights under the TRIPS Agreement's Article 17. The rule that applies to the interpretation of the TRIPS Agreement and other WTO instruments is, however, that one should not add non-negotiated concessions to its text. ${ }^{14}$

\section{Trademarks in major legal systems and the TRIPS Agreement}

1.08 Against the backdrop of a conflict or forced reconciliation between the two major legal systems, what then can one say of the trademark section in the TRIPS Agreement? Does it reconcile civil and common law notions? To a certain extent, it tries to achieve that objective.

1.09 It is well-known that there are two different worldviews when it comes to trademark law, which one could broadly describe here again as civil law and common law approaches. Painting with a very broad brush, one could say that in common law jurisdictions trademark law is derived from the tort of 'passing off'. That is, rights in a trademark typically stem from use in commerce of a symbol to distinguish goods or services from one undertaking from those of a competitor. ${ }^{15}$ Common law would then prevent, under tort doctrines, the use of a confusing mark by a competitor. Unregistered marks are protected at common law, typically only in the geographic area in which they were used and then only against later users. ${ }^{16}$

13 GERVAIS, TRIPS AGREEMENT, supra note 6, at 338-40.

14 DSU, supra note 2, Arts. 3(2) and 19(2).

15 This typically means one or (generally) more arms-length commercial transactions on a product or service in which the mark is featured as a distinctive symbol identifying the supplier or origin of the product or service. For the United States, see Lanham Act § 45, 15 U.S.C. § 1127 (1946), which defines 'Use in Commerce' as follows: 'Use in Commerce. The term "use in commerce" means the bona fide use of a mark in the ordinary course of trade, and not made merely to reserve a right in a mark.'

16 Christopher Wadlow, The LAW of PAssing-OFF 6-12 (3rd ed. 2004). 
The original tort of 'passing off' prevented a merchant from putting another's mark on his wares. ${ }^{17}$ At common law, the existence of protection depended on use in commerce by the plaintiff. ${ }^{18}$ Modern trademark theory has recognized that trademarks protect not only the owners of marks, but also benefit consumers, especially by reducing search costs. ${ }^{19}$ Trademarks allow consumers to identify lawful products that they wish to purchase and to expect a certain quality that they associate with a given trademark. This is an incentive for the trademark owner to maintain its brand.

Various statutes and legal doctrines have added to the arsenal of common law trademark holders over the years, including notions such as 'dilution' in the United States (U.S.) trademark law or protection outside the area where a trademark is actually used. ${ }^{20}$ In spite of the add-ons, however, the notion that basic trademark rights arise from use, not from an act of government, still remains central to all common law systems. Consequently, in most common law jurisdictions obtaining registration of a trademark that is not in use in commerce is not possible. ${ }^{21}$ One may apply for registration but may not complete the registration process without providing adequate evidence of use.

In civil law systems, by contrast, one may apply and obtain registration of a trademark that is not (yet) in use. Trademark rights arise from the administrative act of registration of the trademark. ${ }^{22}$ Unregistered marks are not protected as such, although remedies are often available under general rules concerning unfair or parasitic competition. ${ }^{23}$ This ex ante approach in the role of government in civil law systems is in marked contrast to the approach in common law jurisdictions where the government only intervenes ex post, that

17 Xuan-Thao N. Nguyen, The Digital Trademark Right: A Troubling New Extraterritorial Reach of United States Law, 81 N.C. L. REV. 483, 542-3 (2003).

18 See Aneta Ferguson, The Trademark Filing Trap, 49 IDEA 197, 224 (2009).

19 William M. Landes \& Richard A. Posner, The Economic Structure of Intellectual PROPERTY LAW 185-6 (2003).

204 J. ThOMAs MCCARTHy, MCCARTHy on TRADEMARKS AND UnFAir COMPETITION, § 24:67 (4th ed, 2014). For example, registration of trademark at the United States Patent and Trademark office provides protection throughout the United States even if the mark is not actually used in all 50 States. $I d$. at §26:31 (' $[\mathrm{I}] \mathrm{n}$ the absence of special statutory defenses, or a defect in the registration itself, the owner of a Principal Register registration has superior rights throughout the United States.'). Consonant with common law principles, however, registration is only possible after use in commerce and, for federal registration, use in interstate commerce. Id. at $\S 25: 56$.

21 See generally id.

22 It is true, however, that if a trademark is not used, it will be usually possible to obtain its removal from the register after a certain number of years.

23 In France, such protection is based upon Code Civil [C. CiV.] art. 1382 (Fr.). See ANSElm Kamperman SANDERS, Unfair Competition LAW 28 (1997). For Germany, see Christian Schertz \& Susanne Bergmann, Germany, in CHARACTER MERChANDising IN Europe, 136-7 (Heijo Ruijsenaars ed., 2003). 
is, after use in commerce has begun. The registration process in common law jurisdictions thus recognizes a trademark that is already in existence and use.

1.13 That said, it is worth noting that the purpose of the registration of trademarks is typically not simply for the sake of registration. Trademarks are typically registered so that they can be used. ${ }^{24}$ Put differently, it is relevant in an analysis guided by the object and purpose of the TRIPS Agreement as directed by the application of the Vienna Convention on the Law of Treaties (VCLT) 25 to ask why the TRIPS Agreement gives trademark owners a right to access a registration system and rights against use by third parties to understand the relevant trademark provisions.

\section{The TRIPS Agreement and the Paris Convention}

1.14 With its heavy emphasis on registration, the Paris Convention for the Protection of Industrial Property (Paris Convention) ${ }^{26}$ is arguably a reflection of the civil law approach to trademark protection. Then again, providing rules to simplify registration of marks internationally was the most natural subject matter for an international instrument on trademarks in the 19th century context of World Fairs and emerging international trade, short of specifying uniform minimum substantive trademark rules as happened in the TRIPS Agreement.

1.15 The Paris Convention affords a six-month priority period for trademark owners based in a Paris Member country to apply for registration in a foreign country that is also party to the Paris Convention. The system thus presupposes that a trademark holder will have registered her trademark in country A (typically her country of origin) and then apply for registration in other jurisdictions party to the Paris Convention. Common law jurisdictions had to adapt to this system in a variety of ways. For example, the United States uses a Supplemental Register to register trademarks that are not going to be used in the United States so that they can be 'exported' to other countries under the Paris Convention system. ${ }^{27}$

24 Trademarks are occasionally registered in some jurisdictions for other so-called defensive purposes, but those instances are minimal and also subject to challenge for non-use. See Yasuhiro H. Suzuki, Navigating The 'Land of Harmony' and Finding 'Harmonization' for Foreign Trademark Applicants and Owners: A Japanese Practitioner's Perspective, 103 TRADEMARK REP. 519, 562 (2013).

25 Vienna Convention on the Law of Treaties, 23 May 1969, 1155 U.N.T.S. 331 (entered into force 27 January 1980) [hereinafter VCLT].

26 Paris Convention for the Protection of Industrial Property, as last revised at the Stockholm Revision Conference, 14 July 1967, 21 U.S.T. 1583, 828 U.N.T.S. 303 [hereinafter Paris Convention]

274 MCCARTHY, supra note 20 , at $\$ 19: 33$. 
The TRIPS Agreement went further than the Paris Convention in several respects. The Paris Convention does not define what may constitute a trademark nor does it provide for much in terms of trademark rights or exceptions, other than Article 10bis, which provides substantial protection against various forms of unfair competition. ${ }^{28}$ In contrast, the TRIPS Agreement defines the signs that may constitute trademarks, though it also reflects some level of disagreement about certain types of trademarks, in particular sound and olfactory marks. In such cases, WTO Members are free to determine that only visually perceptible marks can be protected in their country. ${ }^{29}$

\section{THE TRADEMARK PROVISIONS IN THE TRIPS AGREEMENT}

The Chapter now turns to the provisions in the TRIPS Agreement most likely 1.17 to impact trademark transaction rules.

\section{Article 15 of the TRIPS Agreement}

While the TRIPS Agreement does not provide a full trademark code, if read as an entire document while taking its object and purpose into account, it does provide guidance as to WTO Members' shared understandings of the policies and norms relevant to trademarks. ${ }^{30}$

For instance, the function of trademarks can be understood by reference to the TRIPS Agreement Article 15.1, especially its first sentence, which refers to distinguishing goods and services of undertakings in the course of trade. Article 15.1 provides specifically that:

Any sign, or any combination of signs, capable of distinguishing the goods or services of one undertaking from those of other undertakings, shall be capable of constituting a trademark. Such signs, in particular words including personal names, letters, numerals, figurative elements and combinations of colours as well as any combination of such signs, shall be eligible for registration as trademarks. Where signs are not inherently

28 Paris Convention, supra note 26, Art. 10bis.

29 TRIPS Agreement, supra note 1, Art. 15.1. In earlier drafts, the exclusion was applicable to trademarks not capable of 'graphical representation', which might not have excluded certain sound marks and perhaps even some olfactory marks, which are capable of representation using musical notations, descriptions, or chemical formulas.

30 WTO Members' shared understanding might also be described as the intention of the parties to the agreement. 
capable of distinguishing the relevant goods or services, Members may make registrability depend on distinctiveness acquired through use. Members may require, as a condition of registration, that signs be visually perceptible. ${ }^{31}$

Civil and common law systems meet without much effort in the definition of the basic function of a trademark, as explicated in Article 15.1, namely the ability to distinguish the goods or services of one undertaking from those of other undertakings or, simply put, distinctiveness.

\section{The function(s) of trademarks}

1.20 An argument has been made that the purpose of trademarks are merely to separate goods or services in the market place and not to indicate a source or origin. ${ }^{32}$ One can readily agree that trademarks should be capable of performing this distinguishing function. It does not necessarily follow that that is all that a trademark does, however. When one sees the Coca-Cola ${ }^{\circledR}$ trademark on a bottle, it does certainly mean to the average consumer that the product is not $\mathrm{Pepsi}^{\circledR}$ or some other competing soft drink. It would seem fair to add that it performs the function of ensuring to the consumer that the product in the bottle will have the taste and perceived quality that one expects from previous experience, advertising or both. While not specifying a geographic origin (whether the product was made and/or bottled at Coca-Cola Company's headquarters in Atlanta or not is not the point), the trademark also signifies that a well-known company stands behind the product.

1.21 As a commentator explained with respect to U.S. law:

A trademark owner is free to license use of the mark for goods or services, but the licensor must ensure, in some way, that the goods or services with which the mark is used meet the licensor's quality standards. In other words, 'a trademark owner's duty under the Lanham Act not to use the mark in a manner that deceives the public entails a duty to control the quality of its licensees' products.' Reliance on the 'quality assurance' function of trademarks relieves the trademark owner of the burden of active participation, substituting the lesser obligation of quality control..$^{33}$

1.22 Licenses without quality control are sometimes referred to as 'naked licenses' in the U.S. and other legal systems. Under the TRIPS Agreement, WTO

31 TRIPS Agreement, supra note 1, Art. 15.1.

32 Nuno Pires de Carvalho, The trips Regime of Trademarks and Designs 354 (2006). ('Trademarks are not intended to designate the source of goods and services or any other characteristic thereof. They are merely intended to distinguish goods and services.')

33 Michelle S. Friedman, Naked Trademark Licenses in Business Format Franchising: The Quality Control Requirement and The Role Of Local Culture, 10 J. TECH. L. \& POL'Y 353, 359-60 (2005). 
Members may legitimately consider naked licensing as a possible cause to find a trademark is not or is no longer protected in their territory. A U.S. court described the applicable law as follows in a well-known court opinion:

We are all agreed that the Lanham Act places an affirmative duty upon a licensor of a registered trademark to take reasonable measures to detect and prevent misleading uses of his mark by his licensees or suffer cancellation of his federal registration. The Act, 15 U.S.C.A. $\$ 1064$, provides that a trademark registration may be cancelled because the Trademark has been 'abandoned.' And 'abandoned' is defined in 15 U.S.C.A. $§ 1127$ to include any act or omission by the registrant which causes the trademark to lose its significance as an indication of origin. ${ }^{34}$

In other words, trademarks can be seen as performing a distinguishing function that reduces search costs and what one might call a 'trust function', which one could define allowing "buyers to trust and rely upon the signals conveyed by sellers as guarantees for quality, thus helping to prevent the lemonization of markets for goods with experience and credence attributes' ${ }^{35}$ For instance, the name of the Coca-Cola company on a product other than the well-known cola (the company sells drinks such as purified water and orange juice) and even bearing prominently another trademark (here, Dasani ${ }^{\circledR}$ and Minute $\mathrm{Maid}^{\circledR}$ ) might reassure a consumer familiar with $\mathrm{Coke}^{\circledR}$ but not Dasani ${ }^{\circledR}$ that it comes from what one might call, to simplify, a "known or reputable source'.

The melding of the two major legal systems in the TRIPS Agreement admittedly leaves room for substantive trademark law to grow in various directions on this dual function issue (distinguishing and source/quality assurance). What is the impact on the protection of a mark if the owner changes the quality of the goods? Does it lead to a loss of distinctiveness and possibly of the exclusive use of the mark? This is the law in a number of WTO Member countries. ${ }^{36}$ Other WTO Members may decide to deal with such situations primarily as a matter of consumer protection.

34 Dawn Donut Co. v. Hart's Food Stores, Inc., 267 F.2d 358, 369 (1959) 121 U.S.P.Q. 430 (2d Cir. 1959). See also Yamamoto \& Co. (America), Inc. v. Victor United, Inc., 219 U.S.P.Q. 968 (C.D. Cal. 1982) and National Trailways Bus System v. Trailway Van Lines, Inc., 269 F. Supp. 352, 155 U.S.P.Q. 507 (E.D.N.Y. 1965). Courts in the U.S. have made it plain that the quality control mechanism need not be specified in the contract. It may just be derived from actual practice.

35 Ariel Katz, Beyond Search Costs: The Linguistic and Trust Functions of Trademarks, 2010 BYU L. REV 1555, 1563 (2010).

36 For example, in Canada, an Ontario piano manufacturer had outsourced production to Asia without informing consumers. The judge stated that " $t$ ] he function and purpose of a trademark is to indicate the source from which goods emanate. If a mark is associated with a high quality product, its presence will assure the purchaser that the goods are likely to be of that quality. The mark, at least, allows a purchaser to tell whether or not the goods have come from a source in which he or she has confidence ... Not only were the efforts to notify the public virtually non-existent, there was clearly a deliberate attempt by the respondents to 
1.25 The fact that use is required in certain (common law) systems is recognized in Article 15 of the TRIPS Agreement, which also provides that WTO Members may make registrability dependent on use, ${ }^{37}$ but adds that actual use of a trademark shall not be a condition for filing an application for registration. Where signs are not inherently capable of distinguishing the relevant goods or services (for example, the shape or packaging of certain products), registrability may be made dependent on distinctiveness acquired through use. This is consonant with the Paris Convention system described in the previous section of the Chapter. It allows for registration of distinctive signs if registered in their country of origin, but also reflects the flexibility left to WTO and the Paris Convention Members to calibrate rules concerning the distinctiveness of trademarks. Article 6quinquies(B)(ii) of the Paris Convention allows registrability to be denied when a mark is devoid of any distinctive character, which WTO Members may base on acquisition through use if the mark is inherently incapable of distinguishing the relevant goods or services. ${ }^{38}$

1.26 In comparing the TRIPS Agreement with Article 6quinquies(B) of the Paris Convention, and recognising the principle that a mark duly registered in its country of origin should be registered, a mark should be examined on its individual merits, and proper instructions given accordingly to examiners (particularly regarding countries not party to the Paris Convention that are or will become WTO Members). This is reinforced by Article 6quinquies(C) of the Paris Convention, which requires that all factual circumstances be taken into consideration. ${ }^{39}$

1.27 The adaptation of the TRIPS Agreement to the common law world is not limited to the recognition of the validity of a requirement of use. ${ }^{40}$ The definition contained in the first sentence of Article 15.1 of the TRIPS Agreement is not limited to registrable marks. ${ }^{41}$ Thus, especially when read in conjunction with Article 16.142 in fine, the TRIPS Agreement contemplates also rights (for example, the common law tort of 'passing off') in respect of

camouflage the fact that a change of source had occurred.' Heintzman v. 751056 Ontario Ltd, [1990] F.C.1033 (Can.), 34 C.P.R. (3d) 1 (F.C.T.D.). There must be such a difference that the cheaper version must not be of a comparable quality. Jean Patou Inc. v. Luxo Laboratories Ltd., [2001] 67 F.C.1419 (F.C.A.).

37 This applies also to inherently distinctive marks and should thus not be confused with use leading to the acquisition of distinctiveness/secondary meaning of otherwise descriptive marks.

38 Paris Convention, supra note 26, Art. 6quinquies(b)(ii).

39 Id. at Art. 6quinquies(C).

40 E. K. Meltzer, TRIPS and Trademarks, or - GATT Got Your Tongue? 83 TradEMARK REP. 18, 37 (1993) (TRIPS 'incorporates almost every significant concept of United States trademark law').

41 TRIPS Agreement, supra note 1, Art. 15.1.

42 Id., Art. 16.1. 
unregistered marks and provides a framework for such protection, but without mandating their protection in all WTO Members.

The requirement of use and consequences of non-use are impacted also by

Article 19 of the TRIPS Agreement, which limits cancellation for non-use after an 'uninterrupted period of at least three years' if 'valid reasons based on the existence of obstacles to such use are shown by the trademark owner. Circumstances arising independently of the will of the owner of the trademark which constitute an obstacle to the use of the trademark, such as import restrictions on or other government requirements for goods or services protected by the trademark, shall be recognized as valid reasons for non-use.' ${ }^{43}$

\section{Recordal of transfers and licenses under Article 19.2 of the TRIPS Agreement}

The importance of the transactional aspect of Article 19.2 of the TRIPS Agreement seems self-evident. It provides that 'When subject to the control of its owner, use of a trademark by another person shall be recognized as use of the trademark for the purpose of maintaining the registration.' 44

Article 19.2 fills a gap left by the 1958 International Patent and Trademark Conference in Lisbon, Portugal (Lisbon Conference), which was unable to deal effectively only with concurrent use by enterprises that are co-proprietors of a mark (and not licensor and licensee, a much more common situation). The drafting history provides some guidance on the meaning of this provision. There is, however, an interesting nuance in that the term control was chosen to replace consent, the draft was modified as follows during the TRIPS Agreement negotiations (changes shown):

Use of a trademark by another person with subject to the eonsent control of the owner shall be recognized recognised as use of the trademark for the purpose of maintaining the registration. ${ }^{45}$

Article 19.2 implies that a WTO Member must also accept use by a person other than the owner but subject to his control as use that qualifies to maintain the trademark. ${ }^{46}$ Control is often effected by a licensing arrangement enumerating specific conditions under which the mark may be used by the licensee.

43 Id., Art. 19.

44 Id., Art. 19.2.

45 For a more complete description of the drafting history, see GERVAIS, TRIPS AGREEMENT, supra note 6, at $342-5$.

46 TRIPS Agreement, supra note 1, Art. 19.2. 
This puts the spotlight on the control that can and perhaps should be effected by the trademark owner in any licensing transaction and the key role of the specifications (or 'cahier des charges') that a complete trademark license, including franchising arrangement, should comprise. Under Article 19.2 of the TRIPS Agreement, WTO Members have flexibility to require control of the licensee's use by the trademark owner. Control is not the same as consent.

\subsection{As WIPO noted in its Joint Recommendation Concerning Trademark Licenses:}

Certain national or regional laws, however, provide that use by persons other than the holder may be held to constitute use of the mark by the holder only if certain conditions are fulfilled, such as the conclusion of a formal license contract containing quality control clauses or such as the recordal of such a contract. In that respect, it is to be noted that Article 19.2 of the TRIPS Agreement expressly allows a requirement that there be control of a licensee's use of a mark by the holder in order to consider such use valid for maintaining the registration of a mark. ${ }^{47}$

1.32 While the existence of an optional recordal system for licenses and transfers seems acceptable under the TRIPS Agreement rules, there is some disagreement about whether WTO Members may require that a license be registered or 'recorded'. Such registration or recordal may be required under applicable corporate or business licensing laws, tax laws, or other financial regulations not related to intellectual property. Would a WTO Member be allowed not to consider use by an authorized licensee under control of the trademark owner as not sufficient to maintain registration? The text of Article 19.2 of the TRIPS Agreement does not seem to support this conclusion, by making it clear that such use 'shall be recognized' for that purpose.

1.33 The matter was debated during the negotiations, that is, prior to the adoption of the TRIPS Agreement text, at least up to a point. A need to 'control' the use of foreign trademarks by local licensees was felt and justified, during the negotiations, as follows:

It is well recognised that foreign trademarks tend to encourage the production and consumption of non-essential and luxury goods in poorer societies, thereby distorting their socio-cultural objectives and values. Perceptive commentators have drawn attention to the typical and strong tendency in developing countries to imitate the

47 Joint Recommendation Concerning Trademark Licenses, adopted by the Assembly of the Paris Union for the Protection of Industrial Property and the General Assembly of the World Intellectual Property Organization (WIPO) at the Thirty-Fifth Series of Meetings of the Assemblies of the Member States of WIPO 25 September to 3 October 2000, Notes, pp. 6-7, available 14 September 2014 at http://www.wipo.int/edocs/ pubdocs/en/marks/835/pub835.pdf (emphasis added) [hereinafter Joint Recommendation]. 
consumption patterns and life styles of affluent countries, although they may be ill-suited to their own conditions and circumstances. ${ }^{48}$

This control was effected by a number of countries using 'registered user' requirements. As India noted:

The mere authorisation of the use of the trademark by a third party through a private sanction, without the third party being registered as a 'Registered User', shall not constitute use. ${ }^{49}$

The fact that this was raised during the negotiations and that no provision was made in the TRIPS Agreement for the survival of this requirement as a condition to maintain registration is a strong argument against a mandatory requirement to register. This does not mean that registration or recordation of licenses would not be desirable and cannot be effected through other means, however. What it does mean is that sanctions for failure to do so should likely focus not on the validity of the registration or license per se but rather be in the form of administrative measures or adequate fines. This is also WIPO's view on the matter:

The non-recordal of a license with the Office or with any other authority of the Member State shall not affect the validity of the registration of the mark which is the subject of the license, or the protection of that mark. ${ }^{50}$

Some enforcement and evidentiary rules could also be contingent on the 1.35 recordation of licenses. ${ }^{51}$ Finally, the TRIPS Agreement does not prevent the application of competition law where applicable.

\section{Article 20 of the TRIPS Agreement ${ }^{52}$}

Article 20 of the TRIPS Agreement provides as follows:

48 GATT Secretariat, Standards and Principles Concerning the Availability Scope and Use of Trade-Related Intellectual Property Rights: Communication from India, $₫ 32$, MTN.GNG/NG11/W/37 (10 July 1989).

$49 I d$. at 42 . Brazil also made the point around the same time that a 'licensing agreement per se is not evidence of the use of a mark.'. GATT Secretariat, Communication from Brazil, 43, MTN.GNG/NG11/W/57 (11 December 1989). As stated, that seems right, but use by the licensee under the control of the owner would be evidence of use. Brazil then also insisted that 'evidence of use by third parties requires the registration with the relevant government authority of the license granted by the owner of the mark'. Id.

50 Joint Recommendation, supra note 47, Art. 4(1).

51 But see id., Art. 4(2).

52 This section is drawn in part from Susy Frankel \& Daniel Gervais, Plain Packaging and the Interpretation of the TRIPS Agreement 46:5 VAND. J. TRANSNAT'L L. 1149 (2013). 
The use of a trademark in the course of trade shall not be unjustifiably encumbered by special requirements, such as use with another trademark, use in a special form or use in a manner detrimental to its capability to distinguish the goods or services of one undertaking from those of other undertakings. This will not preclude a requirement prescribing the use of the trademark identifying the undertaking producing the goods or services along with, but without linking it to, the trademark distinguishing the specific goods or services in question of that undertaking. ${ }^{53}$

1.37 Article 20 is relevant in trademark transactions in preventing some requirements of use of a trademark with another mark, for example. Whether its prohibition on encumbrances allows WTO Members to completely ban the use of marks is a matter before a WTO Dispute-Settlement Panel at the time of writing. ${ }^{54}$

1.38 Article 20 reflects the function of trademarks in the course of trade, a concept with strong origins in common law trademark doctrines. When interpreting Article 20, the domestic law traditions of any one party to the TRIPS Agreement will not necessarily be determinative. State practice, however, may be relevant to determining the ordinary meaning of terms incorporated in the Agreement when those terms were known to have an agreed meaning, and even an object and purpose, reflective of domestic law. ${ }^{55}$

1.39 The forced combination of a trademark with another by government regulation was examined in an early WTO Dispute-Settlement Panel report. In Indonesia - Certain Measures Affecting the Automobile Industry case, ${ }^{56}$ the United States claimed, inter alia, on the basis of Article 20 that Indonesia had violated its TRIPS Agreement obligations. Its first argument was that:

[a] foreign company that enters into an arrangement with a Pioneer company would be encumbered in using the trademark that it used elsewhere for the model that was adopted by the National Car Programme. ${ }^{57}$

The Panel did not accept this argument for the reason that:

[I]f a foreign company enters into an arrangement with a Pioneer company it does so voluntarily and in the knowledge of any consequent implications for its ability to use any pre-existing trademark. In these circumstances, we do not consider the provisions

53 TRIPS Agreement, supra note 1, Art. 20.

54 For a fuller discussion, see Frankel \& Gervais, supra note 52, at 1149.

55 VCLT, supra note 25, Art. 31.3(b).

56 Panel Report, Indonesia - Certain Measures Affecting The Automobile Industry Case, WT/DS54/R (2 July 1998).

57 Id. at para 14.277. 
of the National Car Programme as they relate to trademarks can be construed as 'requirements', in the sense of Art. 20.58

One argument against this position is that trademark rights are essentially territorial. ${ }^{59}$ One could argue that Article 6bis of the Paris Convention (incorporated into the TRIPS Agreement) supports the U.S. point in respect of well-known marks, however. This opens the door to the question of whether trademark rights as protected under the Paris Convention and the TRIPS Agreement are mere negative nights (to prevent others from using the mark), or whether there are positive rights or privileges to use that are also relevant under such instruments. This issue requires a detailed explanation which the reader may find elsewhere. ${ }^{60}$

Essentially, because participating in the National Car Programme was seen as voluntary - and hence, trademark owners arguably 'accepted' use of the imposed Indonesian mark - the encroachment upon trademark owners' rights was considered not to violate Article 20. This means that the issue of forced use of trademark with another (imposed by regulation) has not been fully explored by a dispute-settlement panel. One may venture that if the function of the trademark was impaired as a result, a WTO Member may have to defend its measure under the justifiability test contained in Article 20.61

At the meeting of the Dispute-Settlement Body discussing adoption of the Panel report, the United States did not object to the adoption (having obtained a favourable ruling on other aspects), but it found the Panel's conclusions on Article 20 'disturbing' and incorrect:

58 Id. at para.14.278 (emphasis added).

59 See Geri L. Haight \& Philip Catanzano, The Effects of Global Priority of Trademark Rights, 91 MASS. L. REV. 18, 25-26 (2007):

While both the Paris Convention and TRIPs recognize the territoriality principle, both create potentially significant exceptions to the doctrine for famous marks. For example, both doctrines contemplate a scenario where a foreign, non-U.S.-based user is given priority rights to a mark, regardless of the level (or absence) of use in the United States. To date, however, there is scant case law in which a U.S. court discussed or applied the provisions of any treaty to a trademark dispute, and it is unclear how much weight U.S. judges will accord to foreign treaties and protocols ... Although most U.S. courts characterize the principle of territoriality as basic to trademark law, some U.S. courts - along with the treaties outlined above - have discussed (although few have applied) a potential exception to this general rule: the 'well known' or 'famous' mark doctrine.

Id. For a U.S. case on point, see De Beers LV Trademark Ltd. v. DeBeers Diamond Syndicate, Inc., 440 F.Supp.2d 249 (S.D.N.Y. 2006).

60 See Frankel \& Gervais, supra note 52.

$61 I d$. (exploring in detail this test). 
In addressing the U.S. claim under the TRIPS Agreement with respect to Indonesia's National Car Programme, the Panel had relied heavily on its conclusions that it was permissible for a government to confer a benefit on condition of a foreign company's relinquishment of the rights afforded under the TRIPS Agreement. [...] In the United States' view, the Panel's conclusions on this point were incorrect, short and devoid of any detailed analysis or discussion of precedent. In particular, the Panel had failed to discuss the GATT and WTO precedents supporting the proposition that there was a requirement in situations where a company had voluntarily accepted conditions in order to receive a benefit. ${ }^{62}$

\section{THE TRADEMARK TRANSACTIONS PROVISION: ARTICLE 21 OF THE TRIPS AGREEMENT}

1.43 The key provision on trademark transactions in the TRIPS Agreement is Article 21. It provides as follows:

Members may determine conditions on the licensing and assignment of trademarks, it being understood that the compulsory licensing of trademarks shall not be permitted and that the owner of a registered trademark shall have the right to assign the trademark with or without the transfer of the business to which the trademark belongs. ${ }^{63}$

\section{Drafting history}

1.44 Let us consider, first, the drafting history. The early draft of 23 July 1990, contained inter alia the following texts:

- Compulsory licensing of trademarks shall not be permitted.

- The right to a [registered] trademark may be assigned with or without the transfer of the undertaking to which the trademark belongs. [PARTIES may require that the goodwill to which the trademark belongs be transferred with the right to the trademark.] [PARTIES may prohibit the assignment of a registered trademark which is identical with, or similar to, a famous mark indicating a state or a local public entity or an agency thereof or a non-profit organisation or enterprise working in the public interest.]

- It will be a matter for national legislation to determine the conditions for the use or assignment of a mark.

63 TRIPS Agreement, supra note 1, Art. 21. 
In October 1990, the text was changed twice, first to this version:

- Compulsory licensing of trademarks shall not be permitted.

- The right to a [registered] The owner of a registered trademark shall have the right to assign his trademark may be assigned with or without the transfer of the undertaking to which the trademark belongs.

- It will shall be a matter for national legislation to determine the conditions for the use or assignment of a mark.

Then to this:

- Compulsory PARTIES may determine conditions on the licensing and assignment of trademarks, it being understood that the compulsory licensing of trademarks shall not be permitted and that the owner of a registered trademark shall have the right to assign his trademark with or without the transfer of the undertaking to which the trademark belongs.

- It shall be a matter for national legislation to determine the conditions for the use of a mark.

In November 1990, the texts were 'combined' as follows to give a text similar

to the final (adopted) version:

PARTIES may determine conditions on the licensing and assignment of trademarks, it being understood that the compulsory licensing of trademarks shall not be permitted and that the owner of a registered trademark shall have the right to assign his trademark with or without the transfer of the undertaking business to which the trademark belongs.

How should one interpret the text? Let us begin with the rule concerning compulsory licenses.

\section{Compulsory licenses of trademarks}

One of the purposes is clear: compulsory licensing of trademarks is prohibited. It is true that, while cases where compulsory licensing of patents may be justifiable in the public interest, it is typically not so with trademarks. Why would a WTO Member want to allow a third party not authorized by the Coca-Cola Company to sell Coke? Local consumers would be 'fooled' into believing that they are purchasing 'the real thing'. Any problem with the product could tarnish the Coca-Cola mark (and company). There is, therefore, no welfare gain for the public nor (obviously) for the trademark owner in allowing this type of free-riding. 
1.50 Since the purpose of trademark is its ability to distinguish the goods or services of one undertaking from those of another, it would be nonsensical to let a third party use that link as identifying the product or service without the consent of (and control by) the trademark owner. Other matters of possible public interest, such as eliminating unused marks from the register, are dealt with in previous Articles. If the use of a patented product is allowed under a compulsory license (say, under the Paragraph 6 System), use of the trademark of the patent holder as an indication could be misleading. ${ }^{64}$

1.51 Under a compulsory licensing regime, how would the licensee not working in cooperation with the trademark owner achieve the level of quality control required to maintain the distinctiveness of the mark? Trademarks perform a distinguishing function from which in many legal systems follows a quality control function: consumers rightly expect consistency of the quality (with variations for items such as food products because the materials used necessarily vary). To say that a trademark compulsory license can or should be issued because a third party (such as a government agency) is regulating the quality of a product ignores the source component of the function. That component is indicated by the direction of Article 15 of the TRIPS Agreement that a mark's purpose is to distinguish the goods or services of one undertaking from those of other undertakings. ${ }^{65}$ As the U.S. Court of Appeals for the Fourth Circuit noted, it is precisely that function that makes a symbol a protected trademark:

When a trademark ceases to identify in the public's mind the particular source of a product or service but rather identifies a class of product or service, regardless of source, that mark has become generic and is lost as an enforceable trademark. See 15 U.S.C. $§ 1064(3)$. To become generic, the primary significance of the mark must be its indication of the nature or class of the product or service, rather than an indication of source. ${ }^{66}$

1.52 While in the case of geographical indications the origin-indicating function is fully intertwined with the quality assurance function, as noted above, this often includes trademarks as well. ${ }^{67}$ Even if third party controls are likely to maintain consistency of the goods, the welfare gains of allowing a product not manufactured by A or with A's consent to be sold as A's product are unclear at best. Consumers can be informed that the product manufactured by $\mathrm{B}$ is

64 That would not prevent nominative use of that trademark.

65 TRIPS Agreement, supra note 1, Art. 15.

66 Glover v. Ampak, Inc., 74 F.3d 57 (4th Cir. 1996).

67 See generally the discussion, supra notes 34 to 36 . On the function of assuring perceived quality that geographical indications perform, see Gervais, supra note 10. 
similar to the product made by $\mathrm{A}$ if nominative (or another similar nonconfusing fair) use of A's mark is allowed.

The TRIPS Agreement ban on compulsory licensing is arguably reinforced by Article 20's prohibition. ${ }^{68}$ The TRIPS Agreement restricts conditions that would be 'detrimental to its capability to distinguish the goods or services of one undertaking from those of other undertakings', and a compulsory license would be likely to do so unless very specific precautions were taken. Fortunately, this is not or no longer a significant issue. Even at the time of the TRIPS negotiation, very few countries allowed the compulsory licensing of trademarks. ${ }^{69}$

\section{Conditions on transfers and licenses and the enforcement of marks}

WTO Members retain the right to determine conditions of transfer and 1.54 assignment. This would include contract provisions requiring, for example, that an assignment be in writing. Can registration or recordal be made mandatory? Not as a condition to maintain registration of the mark, as explained above in relation to Article 19.2 of the TRIPS Agreement. ${ }^{70}$

How does that affect enforcement after (the grant of a) license? As far as enforcement by a licensee is concerned, WIPO notes that whether 'a licensee should be allowed to join proceedings initiated by the licensor, or whether it would be entitled to damages resulting from an infringement of the licensed mark', ${ }^{71}$ a matter left to national law, is not the same as asking whether 'a licensee has the right under the law of a Member State to join infringement proceedings initiated by the holder and to obtain damages resulting from an infringement of the licensed mark'. ${ }^{72}$ In answering the second question, the answer is clear: the licensee should be able to exercise those rights independently of whether the license is recorded or registered.

This debate about enforcement by a licensee against unauthorized use by a third party continued after the adoption of the TRIPS Agreement. At a 1999 meeting at WIPO, "[s]everal delegations and the representative of an observer

68 See supra Part C.4.

69 GATT Secretariat, Existence, Scope and Form of Generally Internationally Accepted and Applied Standards/Norms for the Protection of Intellectual Property - Note prepared by the International Bureau of WIPO, P. 37, MTN.GNG/ NG11/W/24/Rev.1 (15 September 1988).

70 See supra Part C.3.

71 GATT Secretariat,supra note 69 at Note to Article 4. See also Committee of Experts on Trademark Licenses, 70-74, TML/CE/I/3 (30 September 1999).

72 GATT Secretariat, supra note 69 at Note to Article 4. 
organization $[\ldots]$ held that the rights of third parties could depend on recordal and that the licensee could not join in infringement proceedings unless the license was recorded'. ${ }^{73}$ Indeed the Notes to the Joint Recommendation mention that the 'question whether the non-recorded licensee should have the right to join infringement proceedings initiated by the holder and to recover damages was the subject of an intensive debate'. ${ }^{74}$

1.57 Subject to other provisions of the TRIPS Agreement, Members may also allow nominative uses of protected marks.

1.58 It should be noted that the first part of this Article seems to apply to all trademarks (including unregistered marks where they are protected), while the latter part (right to assign) clearly applies only to registered marks.

1.59 Article 21 goes beyond Article 6quater(1) of the Paris Convention which deemed that, in cases where the goodwill or business to which the mark belongs had to be transferred at the same time as the transfer of the mark, transfer of the portion of the goodwill or business located in the country concerned was sufficient. This was fully justified under the principle of independence of rights in different territories. ${ }^{75} \mathrm{~A}$ number of countries did (some still do) require the transfer of the goodwill or business and in some cases, in spite of Article 6quater, required the transfer of the entire business, even if parts of it were located in foreign territories. This is also potentially in conflict with the 'trend' to develop marks as brands with value and existence independently of the goods or services they are associated with.

1.60 The TRIPS Agreement eliminated requirements concerning transfer of the business together with the mark. Business may be defined as 'the industrial or commercial establishment,' that is, the material basis of the activities. ${ }^{76}$ However, contrary to Article 6quater of the Paris Convention, Article 21 does not refer to the 'goodwill'. Bodenhausen, in the well-known Guide to the Paris Convention, defines goodwill as the 'customer base'. ${ }^{77}$ It is difficult to imagine that this element was left out unintentionally. The conclusion that follows from such a choice is that while WTO Members are not permitted to require transfer of the business, as regards transfers of the goodwill only Article

73 Standing Committee on the Law of Trademarks Industrial Designs and Geographical Indications (SCT), Third Session Geneva, 8 to 12 November 1999, 122, SCT/3/10 (26 November 1999).

74 Joint Recommendation, supra note 47 , at Notes para 4.4.

75 G.H.C. Bodenhausen, Guide to the Paris Convention For the Protection of IndustriaL PROPERTY, 104 (WIPO Publ'n, 1969).

76 Id. at 105.

77 Id. 
6quater of the Paris Convention applies (through Article 2.1 of the TRIPS Agreement, which incorporated the substantive provisions of the Paris Convention, including Article 6quater).

This conclusion is reinforced by other expressions used in various texts known to negotiators. For example, Article 5A(4) of the Paris Convention speaks of 'enterprise or goodwill', the former probably a synonym of 'undertaking', a term also used in Article 31(e) of the TRIPS Agreement. ${ }^{78}$ The 1994 Trademark Law Treaty (TLT) is relevant as a contemporaneous instrument negotiated among many of the same parties, though it was concluded a few months after the signing of the WTO Agreement (and the TRIPS Agreement). ${ }^{79}$ Article 11(4)(iv) of the TLT refers to the "business or the relevant goodwill' and does not allow contracting parties, in determining the requirements to be met to record a change of ownership in a trademark, to request that evidence be furnished that the business or relevant goodwill has been transferred with the mark. ${ }^{80}$

\section{A role for competition law?}

Competition law in the TRIPS Agreement, as limited as it is, may also affect trademark transactions. Articles 8.2 and 40.2 of the TRIPS Agreement are relevant in this context. The first one provides that:

Appropriate measures, provided that they are consistent with the provisions of this Agreement, may be needed to prevent the abuse of intellectual property rights by right holders or the resort to practices which unreasonably restrain trade or adversely affect the international transfer of technology. ${ }^{81}$

Article 40.2 reads as follows:

Nothing in this Agreement shall prevent Members from specifying in their legislation licensing practices or conditions that may in particular cases constitute an abuse of intellectual property rights having an adverse effect on competition in the relevant market. As provided above, a Member may adopt, consistently with the other provisions of this Agreement, appropriate measures to prevent or control such practices, which may include for example exclusive grantback conditions, conditions

78 Paris Convention, supra note 26, Art. 5A(4).

79 Trademark Law Treaty, Oct. 27, 1994, available 14 September 2015 at http://www.wipo.int/treaties/en/ip/tlt/ [hereinafter TLT].

80 Id. at Art. 11(4)(iv).

81 TRIPS Agreement, supra note 1, Art. 8.2. 
preventing challenges to validity and coercive package licensing, in the light of the relevant laws and regulations of that Member. ${ }^{82}$

1.63 Article 8.2, in part because the Article is titled 'Principles' and in part because of the 'provided that they are consistent with the provisions of this Agreement' may be seen as a 'policy statement with active force; that is part of the object and purpose of the TRIPS Agreement'. ${ }^{83}$

1.64 Object and purpose is of course of cardinal importance here. The central rule of interpretation and key part of Article 31 of the VCLT requires that a 'treaty shall be interpreted in good faith in accordance with the ordinary meaning to be given to the terms of the treaty in their context and in the light of its object and purpose'. ${ }^{84}$ The VCLT is applicable to the interpretation of the TRIPS Agreement and other WTO instruments. ${ }^{85}$

1.65 Article 40.2 has direct operational force. It establishes the right of WTO Members to specify, on a case-by-case basis (thus excluding a priori determination that a particular practice or licensing condition is anti-competitive leading to the automatic imposition of a remedial measure), practices which must (a) constitute an abuse of intellectual property rights and (b) have an adverse effect on competition (using wording similar but not identical to that used in Article 8 of the TRIPS Agreement).

1.66 A broad definition of 'abuse' without a determination of adverse effect would thus not be consistent with Article 40.2. Indeed, during the negotiation, the possibility of separating these two criteria by an 'or' was discussed at length, but in the end, the wording retained seems to require that both be met simultaneously. In those cases that meet the two required criteria, measures to control or prevent such practices may be taken but only as provided in previous Articles ('as provided above' juxtaposed to 'consistently with the other provisions of this Agreement'). This means that a measure affecting contractual abusive anti-competitive practices may not be taken if it is incompatible with another provision of the TRIPS Agreement, in particular of previous sections of Part II. This requires a balance of the obligation to protect right holders with the need to protect the public from abuses of rights such as coercive package licensing and imposing an obligation to buy goods and services made or distributed by the trademark owner beyond the requirements of the licensee

82 Id., Art. 40.2.

83 Frankel \& Gervais, supra note 52 at 1203

84 VCLT, supra note 25 Arts. 31-32.

85 Appellate Body Report, United States - Continued Existence and Application of Zeroing Methodology, 269, WT/DS350/AB/R (4 February 2009). 
(for example off-patent goods). But competition law may be applied more broadly to ensure the proper functioning of markets. Clauses that limit a licensee's ability to research on or improve the trademark owner's product (more typical in a patent context) could come under this type of scrutiny, as WTO Members try to calibrate their IP regime to optimize local innovation. ${ }^{86}$ Countries should carefully weigh the possible application of investment treaties in this context, especially when legislating rules that apply to existing arrangements. Case-by-case determinations that an existing arrangement violates existing competition law seems less likely to come under the type of scrutiny possible under investment protection schemes. The TRIPS Agreement and the instruments adopted since its implementation clearly favour having fewer (if any) horizontal or per se rules in this context, and point towards greater case-by-case determinations accompanied by adequate due process.

The provisions in the TRIPS Agreement suggest that consultations are to be held between the Member that believes that a contractual practice in a particular case is abusive and anti-competitive and the Member of which the right holder concerned is a national or domiciliary. To explain the role of consultations in this field, it may be useful to recall that practices not unlike those mentioned in this section were discussed in the General Agreement on Tariffs and Trade (GATT) Panels before the Uruguay Round. The emphasis on consultations may reflect the approach taken in those previous attempts to deal with what was termed 'restrictive business practices'. During the GATT Review Session held in 1954 to 1955, a proposal to add a Chapter on 'cartels' (which was Chapter V of the Havana Charter) was rejected. ${ }^{87}$ However, a Group of Experts on 'Arrangements for Consultation' appointed in 1958 to study this matter recommended in a 1960 report that CONTRACTING PARTIES should undertake to deal with restrictive business practices. ${ }^{88}$ That Report, adopted by the CONTRACTING PARTIES, stated that:

[T] he CONTRACTING PARTIES should now be regarded as an appropriate and competent body to initiate action in this field [...] and should encourage direct consultations between contracting parties with a view to the elimination of the harmful effects of particular restrictive practices. ${ }^{89}$

Daniel Gervais, Calibration, in Intellectual Property, Trade And Development, (2nd ed. Daniel Gervais ed, 2015).

87 World Trade Organization, GATT Analytical Index, Vol.I, at p. 486 and Vol.II, at p. 879. B.I.S.D. 3S/51.

88 Report of Experts, Restrictive Business Practices: Arrangement for Consultations, Adopted 2 June 1960, Report L/1015, B.I.S.D. 9S/170.

89 Id. 
1.68 Competition law is not uniform among WTO Members. Indeed, efforts to make it more uniform have so far failed. This provides a significant degree of policy flexibility to WTO Members. For instance, procedurally, it may be applied as ex ante regulation (clearance) of certain transactions. It can be applied ex post by a specialized (typically quasi-judicial) agency or by regular courts. WTO Members may, however, be more cautious in applying remedies that amount to the removal of intellectual property rights as opposed to limits on enforcement or other penalties. More importantly, as noted above, the TRIPS Agreement points to case-by-case determinations, with due process, as signalled by the 'particular cases' clause in Article 40.2.

1.69 The TRIPS Agreement is flexible on substantive conditions on transfers and licensing. The idea that the trademark owner should control uses by the licensee, for example, can be enforced as matter of trademark law, as in the Canadian example above. Because the normative pillars of trademark law in several jurisdictions focus first or at least as much on consumer interests, any license or transfer may be subjected to scrutiny to a test to see whether the transaction led to a loss of distinctiveness. We find an example in a U.S. case, where lack of quality control was described as a cause (if established) to find a mark had been 'abandoned', e.g. via naked licensing. ${ }^{90}$

\section{E. CONCLUSION}

1.70 The TRIPS Agreement impacts trademark transactions by limiting the flexibility of WTO Members in defining what constitutes a trademark, prohibiting compulsory licensing, and restricting conditions on transfers and licenses and possible rules on mandatory use of a trademark with another mark or use in a special form. Disagreements over past disputes and a dispute on plain packaging of tobacco in Australia, which was pending at the time of writing, mean that the exact scope of the obligations imposed on WTO Members in that respect is not entirely clear. The Agreement does, however, leave room for use of trademark law to preserve a quality assurance function and to apply competition law in appropriate cases.

90 See case law cited, supra note 34. 